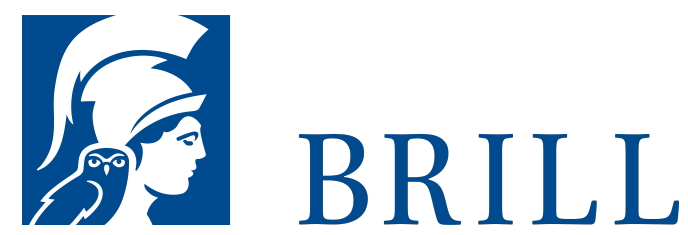

\title{
Menches, Komogrammateus of Kerkeosiris
}

The Doings and Dealings of a Village Scribe in the Late

Ptolemaic Period (120-11o B.C.)

Author: Verhoogt

This is the first study of Menches, village scribe

(komogrammateus) of Kerkeosiris between 120 and 110 B.C., on the basis of the complete body of documents from his archive.

The author first presents and discusses the only source material: the papyri found inside crocodile mummies at the Egyptian village Tebtunis during the winter of 1899/19oo.

After establishing the precise nature of these papyrus documents, the book goes on to explore what we can learn from them about Menches' (re)appointments to the post of village scribe; his position in the Ptolemaic bureaucracy; his contacts written and otherwise - with peers and superiors; his day-to-day tasks, mainly concerned with fiscal land administration; and, in a final chapter, his dealings with a 'strike' of colleague village scribes and a 'strike' of farmers at his village.

\section{Readership}

Papyrologists, Ancient Historians, Legal Historians, as well as Classical Philologists and Egyptologists.

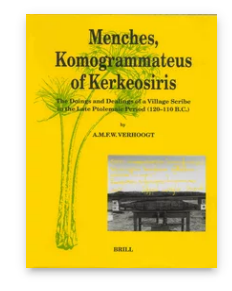

Pages: xiii, 242 pp. 11 illus.

Language:

English

Subjects:

General,

Classical

Studies,

Codicology,

Papyrology \&

Philology,

Ancient Near

East and Egypt

Publisher: Brill

Series:

Papyrologica

Lugduno-

Batava, Volume:

29

E-Book (PDF)

Released online:

og Mar 2020

ISBN: 978-9O-

04-42783-9

List price

USD $\$ 253.00$

Hardback

Publication date:

o1 Dec 1997

ISBN: 978-90-

04-10926-1

List price

USD \$239.00 
Biographical Note

Arthur Verhoogt, D.Phil. (1997), Leiden, is a member of the Papyrological Institute of the University of Leiden, Netherlands.

For more information see brill.com

\author{
Order information: Order online at brill.com \\ +44330 333 o049 | customerservices@brill.com \\ Submission information: brill.com/authors
}

Titles published by Brill | Fink, Brill | mentis or Brill| Schöningh:

+49(o)71 5413279216 | brill@brocom.de 